\title{
Review on Plant Population Density and Row Spacing Effects on Yield of Maize (Zea mays) in Ethiopia
}

\author{
Berhan Getie \\ Department of Plant Science, Faculty of Agriculture and Environmental Science, \\ University of Gondar P.O.Box 138, Ethiopia \\ Tibebu Habitwold (ph.D) \\ Department of Plant Science, Faculty of Agriculture and Environmental Science, \\ University of Gondar P.O.Box 138, Ethiopia \\ Assfachew Eshetie \\ Department of English language and literature, Faculty of social science and humanities, \\ Debark University P.O.Box 143, Ethiopia
}

\begin{abstract}
In this review maize is highly sensitive cereal crop to most agronomic practices such as plant population density and plant spacing. Plant population density and row spacing is one of the best agronomic practice to increase maize crop productivities. Depending on the environmental yield potential of the land, improvements of intera and inter row spacing practices are important for land productivity to each maize varieties. The optimum plant population density that increases the yield and yield components of a single plant. As the review indicates most yield components of maize varieties are affected by plant population density and row spacing due to resource competition results yield reduction. As the plant population increase per cultivated land area, economic yield and above ground biomass yield was decreased. Similarly the narrowest intera and inter row plant spacing decreases economic yield and above ground biomass yield of maize crop.
\end{abstract}

Keywords: population, maize, density, spacing, cob

DOI: $10.7176 / \mathrm{JBAH} / 10-21-02$

Publication date: November $30^{\text {th }} 2020$

\section{CHAPTER 1: INTRODCTION}

\subsection{Background and Justification}

Maize (Zea meys L.) is the most important Mexican originated crop commonly grown as human food and as animal feed. It is also produced throughout the world under diverse environmental condition as a human food in developing country and animal feed in most developed countries. Maize is a versatile cereal crop mostly third next to wheat and rice in the world (CSA, 2017).

It is the most dominant staple food crop found under the category of cereal crops and the most dominant field crop in Africa. On the African continent especially in Ethiopia one of the most field crop ranks second next to teff in area coverage and first in the total production according to (CSA, 2017, kindie T.,2015). Even if the large area under maize crop, the national average yield of maize is bellow the worlds average yield due to the different environmental factors including poor agronomic practice (kindie T., 2015)

Maize production depends on the correct agronomic practice and right application of production inputs like fertilizer and improved seeds to sustain the environment and production. Plant population density and row spacing are the best agronomic cultural practice which had important consideration during optimizing grain and above ground bio-mass yield (Ross L.et al, 2013). In each production system, there is plant population that exploits the utilization of available resources, allowing expression of attainable maize yield on that environment. Mainly the plant population density was highly affected the yield and yield components (cob length, biomass yield and grain yield) of maize crop(Zeleke A et al, 2018), thus, the purpose of this seminar to discuss an overview of the agronomic factors that affect the optimum maize bio-mass and economic yield, to describe the effects of higher plant population than optimum on yield definition and pin point modifications of plant attributes that had contributed to improve maize adaptation to high plant density due to achieving the following objective.

To review the influence of plant population density and row spacing on yield of maize in Ethiopia.

\section{CHAPTER 2: LITERATURE REVIEW}

\subsection{Plant population density}

The interaction between intera and inter row spacing had no effect on radiation, interception and cob weight. Over all interception of radiation and yield per unit area are increased if plant population density increased but yield per plant decreased due to resource computation. The leaf chlorophyll concentration decreased during increasing of plant population due to light competition between plants (Elvis, opoku, 2017). In most maize crop varieties 
biomass yield and grain yield varied along the different land escape position of the field. Land escape position affects on maize productivity smees to be related to the diverse available resources (Bee Khim Chim et al, 2014). High leaf area index with the increasing of planting density due to more leaf area occupied per unit ground area for more light interception and photosynthesis (Zeleke A. et al, 2018)

\subsubsection{Cob}

The diameter and length of cob decreased with the decreasing of row spacing and increment of population density. Densest cobs from the lowest population density might be due to more growth resources (nutrients, soil moisture, carbon dioxide and sun light) are available for crops and the grains become larger. The longest cob with low planting density and widest row spacing due to less resource competition among plants these results to enhance the presence of more number of grains per cob (Zeleke A. et al, 2018). The narrowest plant spacing and high plant population density had intera specific competition among plants for plant development and growth resource, therefore, the supply of growth resource to growing cob is reduced in turn reduce the number of cobs per plant (Mekuannet Belay Kebede, 2019).

\subsubsection{Bio-mass yield}

Plant population density is the presence of number of stands per unit area that enhanced translocation dry matter accumulation on increment of bio-mass yield parallel with an increase in planting density rate (Zeleke A.et al, 2018). The optimum plant population density attained higher dry matter yield, while the population density is high obtained the lowest dry matter yield due to inter plant competition of resource (water, sun light and nutrient) (Hans Kgasago, 2006).

\subsubsection{Grain yield}

Maize grain yield mostly affected by plant population density as compared to other cereal crops due to its morphological characteristics. Increasing grain yield and yield components at low and optimum plant density, whilst at increasing plant density decreasing grain yield due to resource competition such as water, sun light and nutrients (Hans Kgasago, 2006).

\subsection{Row spacing}

\subsubsection{Above ground biomass yield}

The crop grown on optimum spacing efficiently utilize, available resource that resulted increase in height of each individual crop, increase leaf area index and capture more sun light that enable the plant to utilize photosynthesis more efficiently that ultimately leading to accumulation of high amount dray matter (Begizew Golla $e$ t al, 2017).

The above ground bio-mass yield depends on variety. During the closer plant spacing high plant population density per unit area of cultivated land the late maturing varieties had better chance to utilize more nutrients and photosynthetic activities, which ultimately resulted in higher bio-mass production (Mekuannet Belay Kebede, 2019).

\subsubsection{Grain yield}

Grain yield decreased at narrow spacing increased. Due to resource competition in narrow spacing yields were definitely lower than optimum and lower plant spacing (Bee Khim Chim et al, 2014). According to (Gustavo Ángel Maddonni and Joaquín Martínez-Bercovich, 2014), reductions of grain yield were perceived when crops were cultivated in the narrowest row spacing at different land escape position. Maize grain yield high under decreased spacing might be due to efficient utilization of the existing resource such as sun light, water and nutrient (Begizew Golla et al, 2017).

Intera row spacing and inter row spacing had effects on grain and bio-mass yield of maize varieties. Different maize varieties had different response of grain and above ground dry bio-mass yield in inter and intra row spacing. The tallest variety was highly efficient than the short variety due to its ability to convert solar radiation and other growth resource in to economic yield during narrow inter and intera row spacing (Mekuannet Belay Kebede, 2019)

The closest row spacing had high number of plants per unit area of land. Number of plant as per unit area of land varies depending on yield potential of the environmental area of land and varieties itself. Under high rain full and irrigated area high plant population for early planted maize varieties. However under dry land condition less plant population per unit area of land for all varieties of maize crop (Imran et al, 2015).

\section{CHAPTER 3: CONCLUSION AND SUMMARY}

Plant population density and row spacing were affects yield of maize depends on the environmental condition of cultivated area of land and the crop varieties. The tallest variety of maize crop could be tolerating narrow spacing than the shortest variety due to its ability to convert intercepted solar radiation in to grain yield.

Plant population density and row spacing were important cultural practice they were depend on the land resource, rain fall, planting date land escape and variety of the crop. Generally, even if the recommended plant population and row spacing depend on the environmental condition, plant growth resources (nutrient, water, sun light, carbon dioxide) and crop varieties, the closer plant population and narrow spacing decrease yield of maize. 


\section{References}

Bee Khim Chim, Peter Omara, Natasha Macnack, Jeremiah Mullock, Sulochana Dhital, and William Raun,2014.Effect of Seed Distribution and Population on Maize (Zea mays L.)Grain Yield.Department of Plant and Soil Science, Oklahoma State University, Stillwater, OK 74075, USA. Published 9 December 2014Academic Editor: Othmane Merah

Begiew Golla, Adugnaw Mintesnot and Merkeb Getachew, 2017. Impact of Nitrogen Rate and Intra Row Spacing on growth parameters and Yield of Maize at Bako, Western Ethiopia

CSA,2017. Area and production of major crops (private peasant holdings, meher season)

Catherine Waithira njuguna,1 Hellen Wangechi KAMIRI,2John Robert OKALEBO,1 Wilson NGETICH,1 Syphilline KEBENEY, 2016.Evaluating the effect of plant population densities and nitrogen application on the leaf area index of maize in a reclaimed wetland in Kenya.acta universitatis sapientiaeagriculture and environment, 8 (2016) 139148

Elvis Opoku, 2017. Effect of row width and plant population density on yield and quality of maize (Zea mays) silage. Lincoln University Canterbury, New Zealand 2017

Gustavo Ángel Maddonni and Joaquín Martínez-Bercovich, 2014. Row Spacing, Landscape Position, and Maize Grain Yield. Published 14 January 2014Academic Editor: Robert J. Kremer

Hans Kgasago, 2006. Effect of planting dates and densities on yield and yield components of short and ultra-short growth period maize (Zea mays $L$.)

Hans Kgasago, 2006. Effect of planting date, plant density and cultivars on yield and yield components of short and ultra-short growth cultivars at bethlehemand potchefstroom

Kindie T.,2015.Description of cropping systems, climate, and soils in Ethiopia

Mekuannet Belay Kebede,2019.Effect of Inter and Intra Row Spacing on Growth, Yield Components and Yield of Hybrid Maize (Zea mays L.) Varieties at Haramaya, Eastern Ethiopia.http://creativecommons.org/licenses/by/4.0/

Ross L., Stephan C., Mitchell J, Charles S., Jennifer M., 2013. Row spacing and seeding rate recommendations for corn in Nebraska

Shahzad Imran1, Muhammad Arif1, Arsalan Khan, Muhammad Ali Khan2, Wasif Shah1 and Abdul LatifEffect of Nitrogen Levels and Plant Population on Yield and Yield

Components of Maize.http://dx.doi.org/10.4172/2329-8863.1000170 